\title{
A SZÉKELY KÖRVASÚT REGIONÁLIS HATÁSAI
}

\author{
(Regional Effects of the Szekler Circle Railway)
}

\section{KÁNYA JÓZSEF}

Mintegy hat évvel az első angliai vasútvonal megnyitása után, 1836-ban került sor az első magyar vasúti koncepció megfogalmazására (Egyed 1981). A törvény értelmében a Magyar Királyság teruiletén országos vasúthálózatot kívántak kiépíteni. Az első vonalakat 1848-ig átadták a forgalomnak (pl. Bécs-Pozsony-Budapest), de ezek még Erdélyt sem érintették, nemhogy a Székelyföldet.

1848-ban Széchenyi István lett az első felelös magyar kormány közmunka és közlekedési minisztere. Széchenyi vasútépítési koncepciójában már szerepelt az erdélyi és ezen belül a székelyföldi vasút kiépítése. A tervezett országos négy fóvonal közül az egyik a Maros és a Nagyküküllő völgyén keresztül, MarosvásárhelySzékelyudvarhely-Gyimes irányában haladt volna át a Székelyföldön, sőt Galati irányában összeköttetést biztosított volna a Fekete-tengerrel. A korábbi gyakorlattól eltéróen Széchenyi javasolta, hogy a magyar vasútépítést központositott országos felügyelet alatt végezzék. ${ }^{1}$

A forradalom idején azonban nem volt lehetöség a vasúti koncepció gyakorlatban való megvalósítására.

A szabadságharc leverése után Bécs elfogadta Széchenyi koncepcióját, de elsösorban a Bécs környéki területekre helyezték a hangsúlyt, azonban ez is csak 1854-ig tartott, mert a kincstár kimeriult, és kénytelen volt szabad utat engedni a magánbefektetéseknek. Ebben az időszakban egy újabb Erdélyt érintő fôvonalat vázoltak fel Nagyvárad-Királyhágó-Kolozsvár-Brassó-Bodzai-szoros-Galati irányába. Ez csak súrolta volna a Székelyföldet. Természetesen más koncepciók is születtek, de ezek közül 1867-ig egy sem vált valóra.

1867-tel új fejezetéhez érkezett a magyarországi és ezen belül az erdélyi vasútépítés. A kiegyezés alkalmával az új magyar dualista államban a közlekedési ügyeket mind a két ország önállóan intézhette. Ez az időpont azért jelentett fordulópontot Székelyföld életében, mert Andrássy Gyula kormányába Mikó Imrét nevezte ki a közmunka és közlekedési miniszternek. Mikó Imre koncepciójában a vasútépítést vegyes rendszerben képzelte el, állami és magánfinanszírozásban, tapasztalva, hogy a korábbi időszakban a magántársaságokat kizárólag a partikularizmus jegyében a gazdasági érdek motiválta. Az erdélyi gróf programjában tünik fel először az „olcsó vasutak" kérdése (helyi érdekủ vasutak). A miniszteri program külön foglalkozott Erdéllyel, a fövonalon kívül még további fejlesztéseket irányoztak elő. Ezek a fơvonalból ágaztak volna szét Szeben, Marosvásárhely, Székelyföld és Beszterce vidékének irányába (Magyarország... 1867) 
Végül Erdélyben két fó vonalat építettek ki 1867-1873 között (Nagyvárad-Kolozsvár-Tövis-Segesvár-Brassó, valamint Arad-Déva-Gyulafehérvár-Tövis-Segesvár-Brassó), 1873-ban azonban bekövetkezett a pénzügyi válság. A megépített fövonalak elkerülték a Székelyföldet, annak ellenére, hogy Orbán Balázs 1872-ben képviselöházi beszédében hangsúlyozta, hogy a müszaki tervek szerint az északi, erdélyi fövonalnak érintenie kellett volna a Székelyföldet is. A fővonalakból ágaztak ki később a mellékvonalak, amelyekre árufelhordó szerep vărt. Ez a folyamat az 1880-as évektöl datálható, ekkor kezdett a vasút fontos szerepet játszani az erdélyi polgárok életében, elkezdődött a „helyi érdekü” vasutak építése.

„Helyi érdekư" vasutak Európában először Skóciában épültek, általában periférián elhelyezkedő területeken, ahol gyenge a gazdaság teljesítőképessége, a teljes körü finanszírozás nehezen megoldható. Magyarországra Hollán Ernő mérnök-ezredes „hozta be", aki 1848-as emigránsként Franciaországban tanulmányozta a helyi érdekü vasutak rendszerét, melyek lényege az, hogy lehetőleg helyi társulatok építsék, akiknek érdekében áll a térség gazdaságának a bekapcsolása az országos és kontinentális kereskedelembe. Így lehetett elérni, hogy a költségek nagy részét alternatív megoldásokkal lefaragják: nagyon olcsón adták el a kisajátított földeket, az építkezésnél helyi kavicsot, követ, fát használtak, a helybeli munkások otthon étkeztek, aludtak, olcsóbban dolgoztak (Hollán 1864). Nem utolsó sorban a magyar állam is támogatta a helyi érdekủ vasutak építését, a közlekedési tárca részletfizetési kedvezményt adott ha magyar gyáraktól vásárolták a vasúti síneket. 1875-ben megszületett az első törvény Magyarországon, amely lehetővé tette az olcsó vasutak építését ${ }^{2}$. 1880-ban újabb törvényt szavaz meg az országgyülés, konkrétan megfogalmazva az olcsó vasút fogalmát: „vagyis oly vasutak, melyeknek fo célja, hogy az illető vidék forgalmi és közgazdasági igényeinek megfeleljen"3.

A székelyföldi vasútépítés halaszthatatlan volt úgy gazdasági, mint társadalmi, sőt védelmi szempontból. A Székelyföld, mivel Erdély keleti, délkeleti részén helyezkedik el, történelme folyamán mindig egy perifériális régiónak számított úgy földrajzi, kulturális, mint gazdasági, etnikai értelemben, de ugyanakkor összekötö kapocs volt a Moldvai Fejedelemség és később a Román Királyság között. A stratégiai fontosságot egyrészt az indokolta, hogy az 1870-es évek elejére Románia Ploiestitől Pascanig a Kárpátok mentén kiépítette a vonalait, ezzel szemben a Székelyföldön még csak a marosvásárhelyi számyvonal létezett. 1848 előtt Székelyföldről inkább Erdély központi területei felé (Nagyenyed, Gyulafehérvár, Kolozsvár) vándorolt ki a lakosság, az Unió után azonban inkább Budapest felé gravitált. A székelységnek az a része, amely nem földmủveléssel, hanem inkább iparral és kereskedelemmel foglalkozott Moldva és Oláhország irányába vándorolt. Ebben az időszakban a Románia felé vándorlás munka és élelemszerzés céljából meghaladta a szokásos határ menti népmozgásokat, sőt közvetítök útján bonyolódott. A fenti folyamatok a múlt század végére felerósödtek, tarthatatlanná vált a régió gazdasági, szociális állapota. A térség elmaradottságának az volt az oka, hogy távol feküdt a fó közlekedési, kereskedelmi útvonalaktól, a vasút teljes hiánya és az utak rendkívül rossz állapota miatt nem tudott bekapcsolódni a gazdaság vérkeringésébe. Az elma- 
radottság felszámolását, a térség fejlesztésének kiindulópontját a vasút építésétől remélték.

$\mathrm{Az}$ elsődleges cél az volt, hogy a vasútépités révén Székelyföldön olyan ipart teremtsenek, amely helyben biztosítja a lakosságnak a megélhetést. Ennek érdekében a székelyföldi termékeknek belföldön kellett volna biztos piacot teremteni, amelyet nem kezdhet ki a külföldi konkurencia és vámpolitika.

Az erdélyi vasútépítés az 1870-1915-ös időszakot öleli fel, amely egyben a Székely körvasút építésének idejét is jelenti. Azért datálható a körvasút építése már az 1870-es évektöl, mert az erdélyi északi fỏvonal (Nagyvárad-Kolozsvár-TövisSegesvár-Brassó) és egyben a körvasút részét képező Tövis-Marosújvár szakaszt 1871-ben adták át. Ehhez az időponthoz köthetö a Marosújvár-Marosvásárhely szakasz átadása is.

Egy évvel késöbb 1872-ben elkészült a Tövis-Küküllöszeg-Kiskapus-SegesvárHéjjasfalva szakasz, amely az erdélyi déli fövonal (Arad-Déva-GyulafehérvárTövis-Segesvár-Brassó) részét képezte. 1873-ig a déli fövonalat egészen Brassóig kiépítik, amely tulajdonképpen a körvasút egyetlen kelet-nyugat irányultságú déli vonalát képezi Tövis-Segesvár-Brassó vonalon. Az 1873-as év egyben a körvasút elsö épitési szakaszának a végét jelenti. Ezek a vonalak állami támogatással épültek, ezt bizonyítja az a tény is, hogy az 1873-ban bekövetkezö pénzügyi válság után szinte tíz évet kellett várni (az 1888-ban átadott rövid Héjjasfalva-Székelyudvarhelyi szárnyvonalat leszámítva) a következö vonal átadásáig. Erre az időszakra tehetö egy rövid, de fontos szakasznak a megépitése. 1879-ben Brassótól leágazva Bukarest irányában összekötik a magyar vasúthálózatot a Román Királysággal. A románok már korábban kiépítették a vonalat a magyar-román határig. A magyar kormány a pénzügyi nehézségek ellenére kénytelen volt az összeköttetést megteremteni, nemcsak kereskedelmi, stratégiai megfontolásokból (a Tömösi-szoroson át felvett kapcsolat a legrövidebb utat jelentette a román föváros felé), hanem azért is, mert erre a Román Királysággal megkötött nemzetközi szerzödés kötelezte. Brassó és Bukarest összekötése tulajdonképpen azt jelentette, hogy a külkereskedelem egy része erre a vonalra helyezödött át a Temesvár-Versec-Báziás (1867 előtt) és a Temesvár-Lugos-Karánsebes-Orsova (1868-1887) vonalról. A Temesvár-VersecBáziás vonal nem véletlenül épült ki a kiegyezés elött. Egyértelmüen birodalmi érdekeket szolgált, itt tudták a legkönnyebben bekapcsolni a gazdaság vérkeringésébe Resicabánya nyersanyagát és a bánsági svábok termékeit. Ez teljesen természetes, ha csak a bánsági régió érdekeit tartjuk szem elött, de mivel a határ más szakszán (a Kárpátok teljes vonalán) nem volt biztosítva az összeköttetés a Román Királysággal, a báziási és orsovai vasúti határátkelő szivóhatása egész Erdély területén érezhetö volt. A Székelyföldet keletről határoló Kárpátok hágóján vezettek utak a keleti szomszédokhoz, amelyeket évszázadokon keresztül használtak, de a Tömösi-szoroson Bukaresttel biztosított vasúti összeköttetés ezek jelentöségét lokálissá változtatta. A hágókon átvezetö régi kereskedelmi útvonalak ezek után csak a környéken lakók napi kapcsolatait szolgálták. Ezt a tényt a korabeli Székely Müvelödési és Közgazdasági Egylet is fájlalta, szerintük Budapeströl a legrövidebb úton a Fekete-tengert Nagyvárad-Kolozsvár-Marosvásárhely-Okna-Galati irányá- 
ban lehetett volna elérni. Így lehetett volna az osztrák államvasutak baziási és Turnu Severin-i hegemóniáját feloldani. Ez is bizonyítja, hogy a vasút fel, de ugyanakkor le is tud értékelni egy térséget.

1891-ben a Brassó-Sepsiszentgyörgy-Kézdivásárhely szakasz átadásával megkezdödik a székely körvasút épitésének második fázisa. Ez a szakasz már helyiérdekủ vasútként, helyi társaságok finanszírozásával épültt.

A fenti szakasz átadása után, az 1890-es évek első fele többféle elképzelés, álláspont ütköztetésének az időszaka. Természetesen a parlamentben is napirendre került a probléma, az egyes képviselők saját választókörzetük szerint érveltek, amikor a vasút irányvonaláról volt szó.

1891-ben a Marosvásárhelyi Kereskedelmi és Iparkamara is közzétette a programját, amelyben szerepelt, hogy a térség gazdasági problémáinak a megoldását a vasút kiépítésével kell kezdeni. Az Iparkamara vasútépítési stratégiájának az alapja a kelet-nyugati irányultság (ezzel tulajdonképpen visszanyúlnak Széchenyi István koncepciójához) (A marosvásárhelyi... 1892). 1892-ben, egy feliratban Lukács Béla kereskedelmi miniszternek felvázolják a térség gazdasági problémáit. Ezeket csak úgy lehetett volna orvosolni, ha a térséget fỏvonalakkal hálózzák be, majd ehhez kapcsolódnának a helyi érdekủ vonalak (pl. Apahida-Marosvásárhely-Héjjasfalva, Szászrégen-Maroshévíz-Piatra Neamt, Parajd-Gyimes-Tírgu Ocna). A Kamara a Sepsiszentgyörgy-Csíkszereda-Madéfalva-Gyimesbükk vonalat elhibázottnak tekinti, mert nem kelet-nyugat irányultságú. 1892. július 11-én Wekerle Sándor pénzügyminiszter és a közlekedési tárca vezetője között egyeztetések zajlottak a vonalak irányáról, valamint a kivitelezéshez szükséges tökéröl. Közös álláspontként a Sepsiszentgyörgy-Szászrégen és a Csíkszereda-Székelyudvarhely vonal kiépítése kapott prioritást. Ez azonban a nehéz terep miatt rendkívül költséges lett volna, a munkálatok is elhúzódtak volna, így egy időre lemondtak róla (ha elkészült volna, Kelet-Közép-Európa legmagasabban fekvő vasútja lett volna). Ezt követően a könnyebb terepet választották, az Olt völgyében a Sepsiszentgyörgy-CsíkszeredaMadéfalva-Gyimes vonal kiépítésére helyezték a hangsúlyt. 1892. december 13-án lebonyolították a közigazgatási bejárást, kijelölték a vasút nyomvonalát. 1895. március 13-án a képviselőház tárgyalta és elfogadta a Lukács Béla kereskedelmi miniszter által benyújtott törvényjavaslatot. Döntés született arról, hogy a Sepsiszentgyörgy-Madéfalva közötti szakaszt, valamint a gyimesi szárnyvonalat 1897. november 17-ig a közforgalomnak átadják. Tárgyalások kezdődtek a Közmunka és Közlekedési Minisztériummal az elömunkálati engedélyek kiadására. A MÁV megkapta a tervek elkészítésének az engedélyét, a vonal megépítése az új kereskedelmi miniszterre hárult. A szokásostól eltérỏen az állam vette kézbe a vasút építését, az 1891. XL. tc. értelmében. Ez a törvény a magyar-román vasúti csatlakozásnak a gyimesi szoroson történő létesítését írta elö. Ennek a vonalnak a megépítse fontos volt nemcsak kereskedelmi, hanem stratégiai szempontból is. A gyimesi vonal nemcsak a technikai megoldások szempontjából, de a költségeket tekintve is Magyarország egyik legdrágább vasútvonalának számított, mert át kellett tömi az Olt és a Tatros vízválasztóját. Az állam azért volt kénytelen kezébe venni a vasútépítés finanszírozását, mert a korabeli vicinális vasúttörvény alapján épült vasutak 
nem részesültek állami kamatgaranciában. Az engedély-okmányban a helyi érdekü vasutakra kiszabható tarifák, a befektetett építési költségek kamatozását nem biztosították. Ilyen feltételek mellett, figyelembe véve a térség gazdasági elmaradottságát, természetes, hogy sem a hazai, sem a külföldi bankok, sem a magánbefektetők nem yállalták a kockázatot. Csak azok a vidékek tudták önerejükböl fedezni a helyi érdekü vasutak építését, amelyek gazdaságilag prosperáltak, törzsrészvényeket, elsöbbségi kötvényeket tudtak kibocsátani, ily módon biztositva a befektetéshez szükséges tőkét.

A második építkezési láz tulajdonképpen 1896-hoz köthetö, ami nem véletlen, hiszen ekkor az ország a milleniumi megemlékezésekre készült. Az építkezéseket Erdély-szerte igyekeztek időben befejezni. Minden terület törekedett arra, hogy a század nagy vívmányából, az életet jelentő vasútból részesüljön. 1896-ban adják át a forgalomnak a Marosvásárhely-Szászrégen szakaszt is. 1896 októberére a Sepsiszentgyörgy-Csíkszereda-Gyimes vonal is elkészül. Átadására azonban csak 1897. április 4-én került sor. Ugyancsak a milleniumhoz köthetö a Küküllöszeg-Sóvárad vonal átadása 1898-ban. Ezt követően egy újabb 7 éves idószak következett, ez alatt az építkezések szünetelnek.

Az újabb építkezési hullámot az Államvasutak indította el 1905-ben. Ez egyben a körvasút építésének harmadik szakasza. 1906-ban átadták a forgalomnak a Szászrégen-Déda, Sóvárad-Parajd, 1907-ben a Csíkszereda-Gyergyószentmiklós szakaszt, ez utóbbinál áttörve az Olt és a Maros vízválasztóját. 1907-ben Kézdivásárhelyröl Bereckig megközelítették az Ojtozi-szoros irányában a magyarromán határt. 1909-ben a Maros mentén Gyergyószentmiklós és Déda között végül bezárult a Székely körvasút, kialakult a végleges vonalvezetése. 1915-ben még átadták a Marosvásárhely-Parajd szakaszt, és ezzel a székelyföldi vasútépítés véget ért. Sajnálatos módon ez az időszak még napjainkban is tart.

A bemutatott vasútvonalak alapján láthatjuk, hogy a vonalvezetés Erdély-szerte az ösi közlekedési folyósokat követte, a fóvonalak iránya a folyóvölgyekhez igazodott.

A székely körvasút összeköttetést teremtett a székely vármegyék között, bekapcsolta ezeket az erdélyi fövonalakba. A körvasút jellegéböl adódóan, valamint a transzverzális vonalak csaknem teljes hiánya miatt az egyes székelyföldi városok közötti közvetlen kapcsolat csak nagy kerülök árán jöhetett létre.

A székely körvasúttal nem voltak megelégedve sem az utazók, sem az árutermelök, hiszen csak nagy kerülövel, jelentős időveszteséggel, költségekkel jutottak Csík, Gyergyó, Udvarhely termékei a fỏvonalakra és ezáltal a nagyvárosok piacaira. Udvarhelyröl-Marosvásárhelyre 243-km-t kellett vonatozni (ez érvényes a csíki, gyergyói, udvarhelyi, termelökre is) (Szász 1987).

A transzverzális vonalakat mindenképpen ki akarták építeni, ennek érdekében az 1902. augusztus 28-30-án Tusnádfürdőn tartott Székely Kongresszuson több javaslatot dolgoztak ki az újonnan építendö vasútvonalakról, melyek a következők voltak:

1) Kolozsvár-Marosvásárhely között Apahida irányába,

2) Marosvásárhely-Székelyudvarhely között Székelykeresztúr, Gagy, Bözöd, Erdőszentgyörgy irányába, 
3) Székelyudvarhely-Csíkszereda között (a kiépült vonalon 294 km, tehát a menetidỏ 1 nap. A rövidebb út, a Hargitán át $50 \mathrm{~km}$, vasúton 1 óra 7 perc lett volna),

4) Székelyudvarhely-Sepsiszentgyörgy között (Brassó felé 191 km, fél nappal hosszabb, mintha elkészült volna a Homoród-Barót-Málnás vonal, amely 92 $\mathrm{km}$, tehát 1 óra 30 perc lett volna),

5) Székelyudvarhely-Gyergyószentmiklós között (a Bucsin tetőn áthaladva csak $64 \mathrm{~km}$, de csak öt községet kapcsolt volna be, így nem volt gazdasági jelentösége),

6) Szászrégen-Székelyudvarhely-Sepsiszentgyörgy között Nyárádremete, Parajd, Korond és Sepsibükszádon keresztül,

7) Sepsiszentgyörgy és a magyar országhatár, Uzon felé (1 nap gyalog, vasúton 1 óra),

8) Sepsiszentgyörgy-Földvár között is terveztek bekötővonalat, ez felszabadította volna Csíkot és Háromszéket Brassó gazdasági nyomása alól (Borszéki 1905).

A fentiekben felsorolt lehetséges változatok közül talán a legfontosabb a Székelyudvarhely-Csíkszereda és Marosvásárhely-Székelyudvarhely-Sepsiszentgyörgy vonal kiépítése, amellyel létrejöhetett volna az egységes Székelyföld és a székelyföldi gazdasági egység.

Az említett kongresszuson foglalkoztak a székely vasút keleti irányba, Moldva felé való kiépítésével is, amely közvetlen összeköttetést biztosított volna a Feketetengeri kikötőkkel. Borszéki Soma négy indítványt vázolt fel, miközben rámutatott arra, hogy a Fekete-tenger közelségének elönyeit, az elhanyagolt székely ipar és kereskedelem érdekeit csak a nemzetközi vonalak kiépítésével lehet érvényesíteni. Terve alapján Székelyudvarhelyt mint központot összeköttetésbe kellett volna hozni Piatra Neamt felé Odesszával, Gyimes felé Szulinával, Buzau felé Constantaval, és Nagyszeben felé Várnával (Borszéki 1905).

A fenti vonalak közül sajnos egy sem valósult meg, elsodorta az első világháború kitörése és az Osztrák-Magyar Monarchia széthullása.

A XIX. század második felében, a vasút megépitését megelözö időszakban a Székelyföld, a székely medencék gazdaságát viszonylagos elmaradottság jellemezte. Az okok a földrajzi elszigeteltség és a természeti adottságok alacsony kihasználtsága. Az iparosodás a szomszédos régióban elsősorban a szászok által lakott területen bontakozott ki, nem véletlenül, mivel itt régi hagyományokkal rendelkeztek, és a vasút is korábban éreztette jótékony hatását, mivel hamarabb épült ki a dél-erdélyi területeken. Mire a Székelyföldön is kezdett a vasút hatása érvényesülni, a szászok behozhatatlan elönyre tettek szert.

A székelyföldi ipar egyoldalúságát jellemezte, hogy a kezdetleges fafeldolgozás mellett, amely a kivitel abszolút többségét adta, alig néhány gyár létezett. A kereskedelmet a feldolgozóipar hiánya miatt a nyersanyagok és a feldolgozatlan termékek kivitele és a késztermékek behozatala jellemezte (néhány kivételtől eltekintve sajnos napjainkban is ez az uralkodó tendencia). 
A székely körvasút fokozatos kiépítése változtatott az addig fennálló helyzeten.

A vasút megjelenése a Székelyföldön is magával hozta a háttéripar kialakulását (fakitermelés, fafeldolgozás, köbányászat, szénbányászat, vasipar, közlekedési gépipar) és a munkaerő belső piacának fejlődését az áruforgalomba való fokozottabb bekapcsolás révén.

A vasút megjelenésének, fejlődésének köszönhető a kiszélesedő belsỏ piac, a külső piacok könnyebb elérése, a mezögazdasági és ipari jellegủ területek összekapcsolása. A vasút a területi különbségek ellenére meghatározta az egységes nemzeti piac kialakulását. A jobb közlekedési feltételek következtében a piacok kitágultak, a termékek Moldván és Havasalföldön keresztül eljutottak Török- és Görögországba, a vasút nem utolsó sorban szerepet játszott a székelyföldi városok alapiparosodásában (a helyi szükségletek kielégítésében).

A vasút jelentősége megmutatkozik az ipar térhódításában, a gazdasági és kulturális kapcsolatok szorosabbá válásában, a turisztika robbanásszerü fejlódésében. A mai fürdőhelyek közül szinte mindegyik abban az időben épült ki: Borszék, Maroshévíz, Tusnádfürdő, Homoródfürdő, Parajd, Szováta. A turizmus fejlődése főleg Tusnádfürdő gyors fejlödésében mérhető le. A vasút megnyitása (1897) után néhảny év alatt nemzetközi hírnévre tett szert, modern fürdőépületekkel, villákkal, vendéglőkkel turisztikai centrummá épült.

A dualizmuskori fejlödés sajátosságai közé tartozott, hogy visszaszorult a kézmüipar. A városodáshoz hozzájárult a polgári közigazgatási intézményhálózatnak a letelepítése. A városok fejlödését kedvezően befolyásolta (Gyergyószentmiklós és Kézdivásárhely kivételével) az, hogy a megyeszékhelyeken összpontosult az összes fontos hivatal, pl. a vármegye törvényhatósága, a királyi törvényszék és ügyészség, telekkönyvi hatóság, számvevöség, posta, telefon, távirdahivatal.

1890 után részben a hivatalos közbelépésnek és a kedvező gazdasági légkörnek köszönhetően a kisipar mellett egyre több nagyvállalat jelent meg:

- Marosvásárhely - 35 db: téglagyár, gázgyár, sörgyár, cukorgyár, hét építkezési vállalat, bútorgyár, kőolajfinomító, vasöntöde.

- Kézdivásárhely $-17 \mathrm{db}$.

- Sepsiszentgyörgy $-9 \mathrm{db}$

- Udvarhely - $5 \mathrm{db}$

- Csíkszereda $-2 \mathrm{db}$

- Gyergyószentmiklós - 2 db

A gazdasági fellendüléssel párhuzamosan megfigyelhető a kisipar egyes ágazatainak a megszünése. Néhány ágazat nem bírt alkalmazkodni a tökés piaci versenyhez. A Székelyföldre osztrák, cseh, magyar nagyipari vállalatok olcsó áruinak tömege tört be a nyitott kapuk elve alapján. Ezzel a jelenséggel a kis mennyiségben termelö kisipari vállalatok nem tudták felvenni a versenyt.

A vasútépítésnek volt rövid távú, közvetlen hatása is, mert ideiglenes munkalehetőséget biztosított a lakosságnak. Ennek ellenére, érdekes módon a székely vasutak építésénél a munkástömeg elég vegyes összetételü volt, horvátok, bosnyákok, németek, olaszok vettek részt a munkálatokban. A köépítkezéseket olaszok végez- 
ték. Közülük sokan le is telepedtek a környezö településeken, ezt bizonyítják a Fábián, Biscontini családnevek. Az idegen munkások jelenléte jelzi, hogy vagy nem voltak megfelelö szakemberek a Székelyföldön, vagy a nagyméretủ munkanélküliség ellenére a helyi lakosság nem nagyon használta ki a munkalehetöségeket. Többnyire csak beszállítóként dolgoztak, ezért kellett idegen munkaeröt alkalmazni.

Az építkezések nyersanyagszükségletei fellendítették a helyi termelö ipart. A fakitermelés, a Székelyföld legjövedelmezőbb üzleti tevékenysége sem képzelhető el vasutak nélkül, hiszen a századfordulóra a nagytőkéjü társaságok a nagyüzemi kitermelést honosították meg. Becslések szerint a népesség fele valamilyen formában az erdőből élt, az erdők kitermelésénél ök adták a favágókat, fuvarosokat. A nagyipari kitermelés a vasutakkal kezdödött, habár addig is jelentős mennyiségü fát úsztattak le a Maroson, vagy tutajoztak Romániába. A vasút, nemcsak mint szállító befolyásolta az erdőkitermelést, hanem az elsö nagyfogyasztó is volt a talpfák iránti igényével.

$\mathrm{Az}$ építkezések fellendítették a régió élelmiszeriparát (szesz- és malomipar). A külvilággal való szorosabb kapcsolat kialakitása változást idézett elő a székely társadalom életmódjában, úgy az ételek fogyasztása, mint a ruházkodás terén.

A vasutak megjelenése maga után vonta a vasútállomásra vezető utak modernizálását. Élénk építkezés bontakozott ki a székely városok közül a vasúthoz közel fekvő helységekben. Az épülö vasút hatására, pl. Csíkszeredában az építkezési engedélyek megháromszorozódtak az előző időszakhoz képest (A marosvásárhelyi... 1896). A vasúthoz közel fekvő telkek árai megnőttek, áruraktárak, iparvállalatok létesültek.

A századfordulón a székelyföldi városok egy modern polgári város képét mutatták: kórházak, modern bérházak, közmüvelödési és közigazgatási intézmények nőttek ki a földböl.

A vasúthoz köthetö a közúti forgalom és a közszolgáltatások első helyi rendeleti szabályozása. Sor került az országos telefonhálózatba való bekapcsolásra, a városi közvilágítás létesítésére, a vízvezetékrendszer és csatornázás kiépítésére. Csíkszereda esetében a vasúthoz köthető a város elsỏ közparkjának (Erzsébet-park) és teniszpályájának megszületése.

A székelyföldi városok azonban továbbra is elsősorban közigazgatási, kulturális és kereskedelmi központok maradtak. Kivétel Marosvásárhely, amely ipari központtá nőtte ki magát. Itt 1910-ben már 19 magánvállalat müködőtt, és a lakosság száma elérte a 25517 föt. 1910-re a lakosság lassú növekedése figyelhetö meg Székelyudvarhelyen (10 244 fö) és Sepsiszentgyörgyön (8665 fö) is (Egyed 1981, 288).

A fentiekben felvázolt pozitív hatások ellenére a Székelyföld, mivel viszonylag későn (mintegy 50 évvel a vasút Magyarországon való megjelenése után) jutott vasúthoz megőrizte gazdasági elszigeteltségét, kimaradt a fellendülö regionális és nemzetközi kereskedelemböl, a székelyek továbbra is többnyire lokális piacaikra termeltek. Székelyföld, fóleg annak keleti része földrajzilag (és gazdaságilag) távol 
esett a Brassó-Nagyszeben-Kolozsvár-Marosvásárhely városok által közrezárt területtöl, Erdély centrumtérségétöl.

A vasút jelentős mértékben hozzájárult a Székelyföld modernizálásához, városainak fejlődéséhez. A régió a vasút révén kapcsolódott be, ha szerény mértékben is a modern árutermelésbe, ez nyitott utat a modern Európa felé, de ugyanakkor nem jelentette a gazdasági és társadalmi problémák megoldásának kulcsát. Továbbra is jelentős volt a kivándorlás a Kárpátokon túlra és az Amerikai Egyesült Államokba.

Sajnálatos módon napjainkban is tipikusan azokkal a problémákkal kell megküzdenie a Székelyföldnek, mint a múlt század végén és a jelen század elején, csak más dimenzióban (földrajzi elszigeteltség, az utak rossz állapota, a természeti erőforrások nem megfelelő kihasználása). A székelyföldi modernizáció az első világháború és a Monarchia összeomlása miatt nem tudott befejezödni. Ahhoz, hogy az akkor megszakadt modernizáció tovább folytatódjon, a múlt század végi struktúrákhoz kell visszanyúlni, ezekre szervesen építkezve lehet újra elindítani a régió fejlesztését.

A vasúthálózat napjainkban is ugyanaz, mint a század elején, a transzverzális vonalakat máig sem sikerült kiépíteni. Figyelembe véve az eddigi gyakorlatot és az ország jelenlegi gazdasági állapotát, nem remélhető, hogy ezek a vonalak a közeljövöben kiépülnek.

A transzverzális vonalak hiánya miatt a múlt században sem volt és napjainkban sincs biztosítva a székely ,székek” közötti összeköttetés, ezért a Székelyföldnek, mint régiónak a kor kihivásainak megfelelő belső kohéziójáról, gazdasági egységéről nem beszélhetünk.

A belső összekötő vonalak hiánya miatt most is elenyésző a „székközpontok” közötti belső regionális áruforgalom, ami inkább a nagy vasúti csomópontok felé gravitál.

A Székelyföldön áthaladó nemzetközi autópálya sem jelentene alternatívát, hisz remélhetőleg a közeljövöben a turizmus lesz a régió húzóágazata, a levegö tisztaságának megőrzése elsőrendủ feladat. (Ha a gyergyói és a csíki medencén hosszanti irányban végighaladna egy autópálya, föleg a téli idöszakban a medencékben jelentkező hőmérsékleti inverzió, hosszantartó köd miatt lerakodó motorgáz beláthatatlan környezeti és egészségügyi katasztrófát okozna.)

Rövid távon egyetlen lehetséges megoldás a meglévő bekötő utak teljes felújítása, újra építése, amelyeken 30-45 perc alatt el lehetne érni Segesvár és Brassó irányában a még kiépítésre váró autópályát. Nem utolsó sorban fontosnak tartjuk a finom infrastruktúra fejlesztését, a számítástechnikai, telekommunikációs rendszerek kiépitését, hiszen ez a jövő század húzóágazata, az információ gyors áramlása helyettesítheti a fizikai mozgást.

A légi közlekedés is jelenthetne alternatívát, amennyiben a brassói nemzetközi repülőtér kiépülne, és a marosvásárhelyi bővítené szolgáltatásait. A két város a Székelyföld bármelyik részéről 100-150 km-es vonzáskörzeten belül megközelíthető. Természetesen ehhez szintén szükség van a kiváló minőségü bekötő utakra. Azonban a Székelyföldön még egyelöre fölösleges repülöteret építeni, nincs utasforgalom és a gazdaság sem olyan erős, hogy el tudna tartani egy repülőteret. 


\section{Jegyzetek}

1 „Javaslat a magyar közlekedésủgy rendezésérül” - gróf Széchenyi István. Pozsony, 1848, január 25-én.

2 1875. évi XLIV. törvény. Magyar Törvénytár. Budapest, 1896.

${ }^{3}$ 1880. évi XXXI. törvénycikk. Magyar Törvénytár. Budapest, 1896.

\section{Irodalom}

A marosvásárhelyi Kereskedelmi és Iparkamara jelentése kerületének közgazdasági viszonyairól az 189I. évben. (1892) Marosvásárhely.

A marosvásárhelyi Kereskedelmi és Iparkamara jelentése kerületének közgazdasági viszonyairól az 1895. évben. (1896) Marosvásárhely.

Borszéki S. (1905) Székely vasutat a székelységnek. Kiadó nélkül.

Egyed Á. (1981) Falu, város, civilizáció. Bukarest, Kriterion.

Hollán E. (1864) Magyarország forgalmi szükségletei s a vasútügynek üjabb kifejlödése. Pest, Kiadó nétkül.

Magyarország vasúthálózata. (1867) Közli gróf Mikó Imre magyar kir, kỏzmunka és közlekedésủgyi miniszter. Pest, 1-12, o.

Szász Z. (1987) Gazdaság és társadalom a kapitalista átalakulás korában. Erdély története. III. kötet. Köpeczi B. (szerk.), Budapest, Akadémiai Kiadó, 1512-1513. o.

\section{REGIONAL EFFECTS OF THE SZEKLER CIRCLE RAILWAY}

\section{JÓZSEF KÁNYA}

Some six years after the opening of the first railway line in England, the first Hungarian railway plan was being drawn up. The law stated that a national railway network must be built in the territory of the Kingdom of Hungary. The first lines were opened up in 1848 (e.g. Wien-Bratislava-Budapest) but these didn't reach Transylvania not to mentioned Székelyföld (the Hungarian minority populated region in Transylvania). Székelyföld is situated in the eastern or south-eastern part of Transylvania and was always a peripheral region in its history in geography, culture, economics and ethnicity. On the other hand it was a connecting link between the Kingdom of Hungary and the Principality of Moldavia and afterwards the Kingdom of Romania. The building of the Transylvanian railway covers the period of 1870-1915, which was also the term of the building of the Szekler circle railway. The Szekler circle railway created a connection between the Szekler counties and to the Transylvanian main lines. The gradual building of it changed the existing situation in many ways. It contributed to the formation of the background industry (logging industry, quarry operation, coal mining, iron industry, and transportation engineering industry) and the development of the internal labour market through the joining of the region to the circulation of commodities.

The expanding internal market, the improvement of access to external markets and the connection between the agricultural and industrial areas are owed to the appearance and development of the railway. Despite the spatial differences it determined the formation of the common national market. Goods could reach the markets of Turkey and Greece through Moldavia and Havasalföld. 